\title{
The effect of succinylcholine on malignant hyperthermia events in susceptible swine
}

\author{
Frank Schuster ${ }^{1 *}$, Stephan Johannsen ${ }^{1}$, Susanne Moegele ${ }^{1}$, Thomas Metterlein ${ }^{2}$, Norbert Roewer ${ }^{1}$ \\ and Martin Anetseder ${ }^{3}$
}

\begin{abstract}
Background: While the impact of volatile anaesthetics to induce malignant hyperthermia $(M H)$ is abundantly clear, the role of succinylcholine still remains controversial. To evaluate the influence of succinylcholine on porcine $\mathrm{MH}$ events, the authors investigated the hemodynamic and metabolic responses in $\mathrm{MH}$ susceptible (MHS) and non-susceptible (MHN) swine following either succinylcholine or halothane application alone or a combination of both substances.

Methods: With approval of the local animal care committee $27 \mathrm{MHS}$ and $30 \mathrm{MHN}$ pigs were anaesthetized and mechanically ventilated. Fiberoptic probes for continuous $\mathrm{PCO}_{2}$ measurement were inserted into the femoral vein and the triceps muscle. Group A received succinylcholine $4 \mathrm{mg} / \mathrm{kg}$, group B incremental doses of halothane (0.5, 1.0 vol\%) and group C succinylcholine and halothane simultaneously. Vital signs were recorded continuously.

Results: Prior to drug application measured values did not differ between MHS and MHN. While MHN pigs did not show relevant alterations, succinylcholine, halothane and the combination of both lead to significant hemodynamic and metabolic changes in MHS swine.

Conclusions: Hemodynamic and metabolic alterations following succinylcholine were similar to halothane in MHS pigs. The combination of both pharmacological agents potentiated the observed effects. According to these results succinylcholine acted as an independent and supportive factor during onset of an $\mathrm{MH}$ episode.
\end{abstract}

Keywords: Malignant hyperthermia, Succinylcholine, Halothane, Swine

\section{Background}

Malignant hyperthermia $(\mathrm{MH})$ is a potentially lethal pharmacogenetic disorder characterized by a disturbance of skeletal muscle calcium homeostasis. In predisposed humans and animals exposure to triggering agents may lead to a hypermetabolic muscular syndrome. Uncontrolled sarcoplasmic calcium release caused by mutations in the ryanodine receptor subtype 1 or in the dihydrophyridine receptor results in hypoxemia, hypercapnia, tachycardia, muscular rigidity, acidosis, hyperkalaemia and hyperthermia [1]. While the impact of volatile anaesthetics in the development of $\mathrm{MH}$ is abundantly clear, the role of the depolarising muscle relaxant succinylcholine (SCh) still remains controversial [2]. For instance, application

\footnotetext{
*Correspondence: schuster_f@ukw.de

'Department of Anaesthesia and Critical Care, University of Wuerzburg,

Oberduerrbacher Straße 6, D-97080 Wuerzburg, Germany

Full list of author information is available at the end of the article
}

of commonly used halogenated anaesthetics induces pathological muscular contractions in muscle bundles of susceptible patients in vitro [3], whereas SCh did not induce a reproducible muscular response [4]. Furthermore, reliable reports of fulminant $\mathrm{MH}$ episodes in humans or animals induced by administration of SCh alone are lacking in the current literature [2].

Hence, the aim of the present study was to investigate the hemodynamic and metabolic response in $\mathrm{MH}$ susceptible (MHS) and non-susceptible (MHN) pigs following application of SCh, halothane or the combination of both pharmacological agents, to evaluate the influence of SCh on porcine $\mathrm{MH}$ events.

\section{Methods}

\section{Experimental protocol}

With approval of the local animal care committee (Government of Unterfranken, Wuerzburg, Germany, 
application number: 44/99; 14/05), 57 pietrain pigs weighing $30.6(27.8$ - 31.5) $\mathrm{kg}$ were examined. Prior to the investigation, $\mathrm{MH}$ susceptibility or wild type was determined by DNA analysis regarding the presence of a homozygous arginine 615 mutation of the ryanodine receptor indicating MHS.

Anaesthesia was induced intravenously via an ear vein with thiopental $(14-17 \mathrm{mg} / \mathrm{kg})$ and maintained using a midazolam $(0.2-0.4 \mathrm{mg} / \mathrm{kg} / \mathrm{h})$ and fentanyl $(0.01-0.04 \mathrm{mg} / \mathrm{kg} / \mathrm{h})$ infusion in all swine. After the trachea was intubated $(7.0 \mathrm{~mm}$ ID endotracheal tube, Rüsch, Kernen i.R., Germany) without the use of muscle relaxants, ventilator settings (Servo 900C, Siemens, Erlangen, Germany) were adjusted to keep an end-tidal carbon dioxide partial pressure $\left(\mathrm{PCO}_{2}\right)$ of $30-35 \mathrm{mmHg}$ (respiratory rate: 12 - 14/min; tidal volume: $10-15 \mathrm{~mL} / \mathrm{kg}$; positive end expiratory pressure: $5 \mathrm{mmHg} ; 50 \%$ oxygen and $50 \%$ air). Afterwards, two $\mathrm{PCO}_{2}$ probes (ParaTrend 7+, Diametrics Medical Inc., High Wycombe, Buckinghamshire, UK) were placed under ultrasound guidance into the left triceps muscle and into the left femoral vein of the animals. Vital signs of the animals were monitored continuously by mean arterial blood pressure (MAP) in the saphenous artery, peripheral oxygen saturation $\left(\mathrm{SaO}_{2}\right)$, ECG and rectal temperature. A warming blanket and an infrared lamp were used to prevent the animals from hypothermia. In 15 minutes intervals arterial blood samples were obtained and immediately analysed for $\mathrm{pH}$, arterial oxygen partial pressure $\left(\mathrm{PaO}_{2}\right)$, carbon dioxide partial pressure $\left(\mathrm{PaCO}_{2}\right)$, base excess $(\mathrm{BE})$ and lactate. Throughout the experiment $4 \mathrm{~mL} / \mathrm{kg} / \mathrm{h}$ Ringer solution (B. Braun, Melsungen, Germany) was administered via a central venous line placed in the right jugular vein.

After stable conditions were achieved, animals were subdivided into three groups. Following baseline recording, the SCh group (MHS: $n=9$; MHN: $n=10$ ) received two single boluses of SCh $4 \mathrm{mg} / \mathrm{kg}$ (Nycomed Pharma $\mathrm{GmbH}$, Unterschleissheim, Germany) at intervals of 15 minutes, while in the halothane group (MHS: $\mathrm{n}=6$; MHN: $\mathrm{n}=10$ ) the anaesthetic vapor setting was adjusted to achieve an end-tidal halothane concentration of $0.5 \mathrm{vol} \%$ for the first 15 minutes, followed by an elevation to $1 \mathrm{vol} \%$ for further 15 minutes. In a third group (MHS: $\mathrm{n}=12 ;$ MHN: $\mathrm{n}=10$ ) a single bolus of SCh $4 \mathrm{mg} / \mathrm{kg}$ combined with an end-tidal halothane concentration of $0.5 \mathrm{vol} \%$ was applied at first and was augmented after 15 minutes by another SCh bolus $4 \mathrm{mg} / \mathrm{kg}$ and an increase of halothane to $1 \mathrm{vol} \%$. Different sizes of the investigated groups were caused by the availability of the animals. Intramuscular and femoral venous $\mathrm{PCO}_{2}$ were recorded in 1-minute intervals. Arterial blood samples were analysed before and after drug application. Systemic hemodynamic parameters were monitored throughout the experiment. The clinical occurrence of
$\mathrm{MH}$ was defined as the development of at least four out of six conditions: arterial $\mathrm{pH} \leq 7.20, \mathrm{PaCO}_{2} \geq$ $50 \mathrm{mmHg}$, arterial $\mathrm{BE} \leq-5 \mathrm{mmol} / \mathrm{l}$, lactate $\geq 5 \mathrm{mM}$, end-tidal $\mathrm{PCO}_{2} \geq 45 \mathrm{mmHg}$ and an increase of rectal core temperature $\geq 38.5^{\circ} \mathrm{C}$ [5].

\section{Carbon dioxide measurements}

The fiberoptic $\mathrm{PCO}_{2}$ sensor consisted of an optode, kept in a heparin-coated microporous polyethylene tube of approximately $0.5 \mathrm{~mm}$ in diameter and permeable to the substance to be measured. The cylindrical sensor construction allowed measurements over the entire probe surface. Prior to insertion in the target tissue, the probes were calibrated in vitro by exposure to different standard gas concentrations (TrendCare Calibrator, Diametrics Medical Inc., High Wycombe, Buckinghamshire, UK).

\section{Statistical analysis}

Data are displayed as median and interquartile range. Statistical comparisons between and within the investigated groups were performed by repeated measures ANOVA and post-hoc Tukey test. A value of $\mathrm{p}<0.05$ was considered statistically significant.

\section{Results}

\section{Clinical occurrence of $\mathrm{MH}$}

According to the predefined metabolic parameters none of the MHN swine developed any clinical signs of an $\mathrm{MH}$ episode after application of SCh, halothane or both agents. In contrast, MH occurred in all MHS animals of the halothane and the SCh plus halothane group, while only four out of nine MHS pigs in the SCh group fulfilled the defined criteria.

\section{Hemodynamic data}

Prior to drug application hemodynamic variables and rectal temperature were comparable between the investigated groups. While in MHN swine SCh had little or no effect on hemodynamic parameters, relevant hypotension, tachycardia and an increase in end-tidal $\mathrm{PCO}_{2}$ were observed in all MHS animals. However, SCh did not induce a rise of body temperature in the MHS pigs.

Interestingly, incremental concentrations of halothane caused a significant decrease of arterial blood pressure in both investigated groups, while increases of end-tidal $\mathrm{PCO}_{2}$ only became significant in MHS swine. But, neither heart rate nor rectal temperatures were significantly affected by halothane application in normal or susceptible animals.

In contrast, the effects of halothane combined with $\mathrm{SCh}$ were numerous and pronounced. Beside distinctive hypotension and tachycardia, a significant temperature increase was noticed in MHS pigs. Furthermore, changes in end-tidal $\mathrm{PCO}_{2}$ were significantly different between 
susceptible and normal animals. It is noteworthy, that eleven of the twelve MHS pigs immediately died after reinjection of SCh and raise of end-tidal halothane concentration to 1 vol\%. Even MHN pigs developed significant hypotension and tachycardia after administration of halothane plus SCh (Table 1).

\section{Metabolic data}

\section{Arterial blood gas samples}

There were no significant metabolic differences in arterial blood samples prior to $\mathrm{SCh}$, halothane or SCh and halothane application between MHS and MHN swine. With exception of minor $\mathrm{PaO}_{2}$ alterations, neither SCh nor halothane or the combination of both agents resulted in serious changes of metabolic variables in the MHN groups. However, in MHS animals SCh alone caused a significant and severe decrease in $\mathrm{pH}$ and $\mathrm{BE}$ and a relevant increase of $\mathrm{PaCO}_{2}$ and serum lactate.
Systemic halothane aggravated the metabolic alterations in the MHS group. Furthermore, simultaneous application of halothane and $\mathrm{SCh}$ resulted in an earlier and more distinctive metabolic deterioration and was lethal for the majority of the MHS pigs (Table 2).

\section{Muscular and femoral venous carbon dioxide measurements}

Intramuscular and femoral venous baseline $\mathrm{PCO}_{2}$ levels before trigger application were comparable between the investigated MHS and MHN animals. In MHN pigs no differences in muscular or venous $\mathrm{PCO}_{2}$ values were recorded at any experimental time point following $\mathrm{SCh}$ and/or halothane application (Table 3 and Table 4). In contrast, intravenous SCh and systemic halothane respectively resulted in a significant increase of femoral venous $\mathrm{PCO}_{2}$ in MHS pigs. In addition, simultaneous application of SCh and halothane induced an even more

Table 1 Hemodynamic variables of malignant hyperthermia susceptible (MHS) and non-susceptible (MHN) pigs following succinylcholine or halothane or succinylcholine and halothane application

\begin{tabular}{|c|c|c|c|c|c|c|}
\hline Diagnose & Time $[\mathrm{min} \mid$ & HR [bpm] & MAP [mmHg] & $\mathrm{SaO}_{2}[\%]$ & etCO ${ }_{2}[\mathrm{mmHg}]$ & Temperature $\left[{ }^{\circ} \mathrm{C}\right]$ \\
\hline \multirow{4}{*}{$\mathrm{MHS}_{\mathrm{SCh}}(\mathrm{n}=9)$} & $0 \mathrm{~min}$ & $53[52-61]$ & 84 [83-89] & 98 [98-98] & $35[31-35]$ & $37,3[37,1-37,3]$ \\
\hline & $15 \mathrm{~min}$ & $58[53-65]$ & 85 [82-89] & 98 [97-98] & 35 [32-36] & $37,2[37,0-37,3]$ \\
\hline & $30 \mathrm{~min}$ & $73[63-85]^{*}$ & $67[55-74]^{*}$ & 98 [97-98] & $48[42-51]^{* \#}$ & $37,5[37,2-37,5]$ \\
\hline & $45 \mathrm{~min}$ & $70[68-92]^{*}$ & $66[60-76]^{*}$ & 98 [97-98] & $54[44-62]^{* \#}$ & $37,6[37,3-37,9]$ \\
\hline \multirow{4}{*}{$\mathrm{MHN}_{\mathrm{SCh}}(\mathrm{n}=10)$} & $0 \mathrm{~min}$ & $67[63-72]$ & 75 [70-86] & 99 [97-100] & $33[30-35]$ & $37,0[36,8-37,5]$ \\
\hline & $15 \mathrm{~min}$ & 71 [63-75] & 74 [67-81] & 99 [96-100] & 33 [30-35] & $36,9[36,7-37,4]$ \\
\hline & $30 \mathrm{~min}$ & 72 [67-75] & $72[68-76]$ & 99 [98-100] & $34[31-34]$ & $37,0[36,6-37,4]$ \\
\hline & $45 \mathrm{~min}$ & $66[61-70]$ & $71[69-76]$ & 99 [97-100] & 34 [31-35] & $37,0[36,6-37,4]$ \\
\hline \multirow{4}{*}{$\mathrm{MHS}_{\text {Halothane }}(\mathrm{n}=6)$} & $0 \mathrm{~min}$ & $61[60-66]$ & $82[75-84]$ & 98 [98-99] & 33 [30-35] & $37,4[36,9-37,5]$ \\
\hline & $15 \mathrm{~min}$ & $58[55-66]$ & $82[76-87]$ & 98 [97-99] & 33 [30-34] & $37,4[36,9-37,4]$ \\
\hline & $30 \mathrm{~min}$ & $61[59-64]$ & $49[45-53]^{* \#}$ & 98 [97-99] & $36[32-40]^{*}$ & $37,3[37,0-37,5]$ \\
\hline & $45 \mathrm{~min}$ & $76[61-110]$ & $41[38-45]^{*}$ & 97 [95-98] & $55[44-65]^{*}$ & $37,5[37,1-37,9]$ \\
\hline \multirow{4}{*}{$\mathrm{MHN}_{\text {Halothane }}(\mathrm{n}=10)$} & $0 \mathrm{~min}$ & 64 [57-70] & 72 [70-79] & 98 [98-100] & 33 [31-35] & $36,8[36,6-37,3]$ \\
\hline & $15 \mathrm{~min}$ & $64[55-69]$ & 73 [68-80] & 98 [97-99] & 35 [31-35] & $37,0[36,8-37,2]$ \\
\hline & $30 \mathrm{~min}$ & $68[61-76]$ & $66[55-72]^{*}$ & 99 [98-100] & 33 [31-34] & $37,1[36,6-37,2]$ \\
\hline & $45 \mathrm{~min}$ & 69 [62-73] & $51[45-56]^{*}$ & 99 [97-100] & $31[29-33]^{* \#}$ & $37,0[36,8-37,3]$ \\
\hline \multirow{4}{*}{$\mathrm{MHS}_{\text {Halothane+SCh }}(\mathrm{n}=12)$} & $0 \mathrm{~min}$ & $65[55-87]$ & 60 [59-72] & 98 [98-99] & 31 [30-32] & $37,5[37,4-37,9]$ \\
\hline & $15 \mathrm{~min}$ & $80[70-92]^{*}$ & $60[55-75]$ & 98 [97-99] & $33[32-34]^{*}$ & $37,5[37,3-37,8]$ \\
\hline & $30 \mathrm{~min}$ & $168[113-204]^{* \#}$ & $41[35-45]^{*}$ & $96[95-98]^{*}$ & $63[55-65]^{* \#}$ & $38,0[37,6-38,2]^{* \#}$ \\
\hline & $45 \mathrm{~min}$ & $200+$ & $60+$ & $98+$ & $79+$ & $39,5+$ \\
\hline \multirow{4}{*}{$M H N_{\text {Halothane+SCh }}(n=10)$} & $0 \min$ & $71[61-79]$ & $67[60-80]$ & 99 [97-99] & 33 [31-33] & $37,6[37,1-37,8]$ \\
\hline & $15 \mathrm{~min}$ & $83[73-97]^{*}$ & $61[60-78]$ & 98 [97-99] & $32[31-34]$ & $37,2[37,1-37,6]^{*}$ \\
\hline & $30 \mathrm{~min}$ & $93[84-102]^{*}$ & $57[53-60]^{*}$ & 98 [96-98] & $31[30-32]$ & $37,0[36,8-37,5]^{*}$ \\
\hline & $45 \mathrm{~min}$ & $100[95-105]^{*}$ & $52[48-60]^{*}$ & 96 [95-100] & $32[30-32]$ & $36,9[36,7-37,4]^{*}$ \\
\hline
\end{tabular}

$\mathrm{t}=0$ minutes: Baseline values; $\mathrm{t}=15$ minutes: Application of $4 \mathrm{mg} / \mathrm{kg}$ succinylcholine or $0.5 \mathrm{vol} \%$ halothane or both; $\mathrm{t}=30 \mathrm{minutes}$ : Application of $4 \mathrm{mg} / \mathrm{kg}$ succinylcholine or 1 vol\% halothane or both.

$\mathrm{HR}=$ heart rate; $\mathrm{MAP}=$ mean arterial blood pressure; $\mathrm{SaO}_{2}=$ peripheral oxygen saturation; et $\mathrm{CO}_{2}=$ end-tidal carbon dioxide; $\mathrm{SCh}=$ succinylcholine.

Data as median and interquartile range;

*significant changes from baseline values; " significant differences between MHS and MHN; $\mathrm{p}<0.05$. +: data from only one MHS animal. 
Table 2 Arterial blood gas samples of malignant hyperthermia susceptible (MHS) and non-susceptible (MHN) pigs following succinylcholine or halothane or succinylcholine and halothane application

\begin{tabular}{|c|c|c|c|c|c|c|}
\hline Diagnose & Time $[\mathrm{min} \mid$ & $\mathrm{pH}$ & $\mathrm{PaO}_{2}[\mathrm{mmHg}]$ & $\mathrm{PaCO}_{2}[\mathrm{mmHg}]$ & $\mathrm{BE}[\mathrm{mmol} / \mathrm{l}]$ & Lactate $[\mathrm{mM}]$ \\
\hline \multirow{4}{*}{$\mathrm{MHS}_{\mathrm{SCh}}(\mathrm{n}=9)$} & 0 min & $7,38[7,36-7,44]$ & 260 [242-285] & $40[38-43]$ & $0,5[-1,7-1,2]$ & $0,5[0,4-0,7]$ \\
\hline & $15 \mathrm{~min}$ & $7,39[7,37-7,44]$ & 282 [263-298]\# & $40[38-42]$ & $0,0[-1,7-1,2]$ & $0,5[0,4-0,6]$ \\
\hline & $30 \mathrm{~min}$ & $7,21[7,11-7,22]^{* \#}$ & 243 [194-269] & $59[55-66]^{* \#}$ & $-4,6[-9,2--3,6]^{* \#}$ & $2,7[2,2,3,2]^{* \#}$ \\
\hline & $45 \mathrm{~min}$ & $7,19[7,11-7,23]^{* \#}$ & 240 [229-255] & $64[57-72]^{* \#}$ & $-3,7[-9,2--3,6]^{\# \#}$ & $1,5[1,2-1,8]^{* \#}$ \\
\hline \multirow{4}{*}{$\mathrm{MHN}_{\mathrm{SCh}}(\mathrm{n}=10)$} & $0 \mathrm{~min}$ & $7,42[7,37-7,45]$ & 246 [187-274] & 42 [39-43] & $2,0[-0,2-2,6]$ & $0,7[0,5-0,9]$ \\
\hline & $15 \mathrm{~min}$ & $7,42[7,37-7,43]$ & 249 [197-266] & $42[40-45]$ & $1,8[-0,4-2,5]$ & $0,6[0,5-0,7]$ \\
\hline & $30 \mathrm{~min}$ & $7,40[7,36-7,44]$ & 233 [183-271] & 43 [39-46] & $2,7[0,3-3,0]$ & $0,6[0,5-1,0]$ \\
\hline & $45 \mathrm{~min}$ & $7,39[7,36-7,44]$ & 253 [198-268] & $44[39-46]$ & $1,4[-0,4-2,4]$ & $0,6[0,5-0,7]$ \\
\hline \multirow{4}{*}{$\mathrm{MHS}_{\text {Halothane }}(n=6)$} & $0 \mathrm{~min}$ & $7,38[7,34-7,39]$ & 260 [257-270] & 40 [39-41] & $-1,2[-2,5--0,4]$ & $0,6[0,5-0,7]$ \\
\hline & $15 \min$ & $7,39[7,36-7,42]$ & 265 [257-265] & 39 [38-40] & $-0,2[-1,5-0,4]$ & $0,5[0,4-0,6]$ \\
\hline & $30 \mathrm{~min}$ & $7,29[7,19-7,38]$ & 254 [248-259] & $48[41-52]$ & $-3,2[-8,9--0,4]$ & $2,4[1,7-5,1]$ \\
\hline & $45 \mathrm{~min}$ & $7,03[6,99-7,09]^{* \#}$ & 212 [192-247] & $67[58-77]^{* \#}$ & $-12,3[-15,1--10,8]^{* \#}$ & $9,0[8,2-9,9]^{* \#}$ \\
\hline \multirow{4}{*}{$\mathrm{MHN}_{\text {Halothane }}(\mathrm{n}=10)$} & $0 \mathrm{~min}$ & $7,39[7,35-7,42]$ & 247 [201-279] & $43[39-46]$ & $0,5[-1,5-1,1]$ & $0,6[0,5-0,8]$ \\
\hline & $15 \min$ & $7,38[7,33-7,42]$ & 249 [195-276] & $43[39-46 \mid$ & $0,0[-1,8-0,9]$ & $0,8[0,6-1,0]$ \\
\hline & $30 \mathrm{~min}$ & 7,39 [7,35-7,49] & 238 [200-253] & $42[38-46]$ & $-0,3[-2,2-0,8]$ & $0,9[0,5-1,1]$ \\
\hline & $45 \mathrm{~min}$ & $7,39[7,34-7,40]$ & $232[179-259]^{*}$ & 40 [39-44] & $-1,0[-2,6-0,6]$ & $0,6[0,5-1,0]$ \\
\hline \multirow{4}{*}{$\mathrm{MHS}_{\text {Halothane+SCh }}(\mathrm{n}=12)$} & $0 \mathrm{~min}$ & $7,47[7,41-7,51]$ & $256[250-281]$ & 36 [32-37] & $2,4[0,3-4,6]$ & $1,1[0,9-1,4]$ \\
\hline & $15 \mathrm{~min}$ & $7,42[7,33-7,44]^{*}$ & $261[247-271]$ & $39[38-44]^{*}$ & $0,1[-2,6-2,1]$ & $3,1[1,6-3,6]$ \\
\hline & $30 \mathrm{~min}$ & $6,90[6,83-7,13]^{* \#}$ & $256[194-314]^{\#}$ & $69[33-87]^{* \#}$ & $-18,6[-23,3--15,0]^{* \#}$ & $15,7[15,3-21,4]^{* \#}$ \\
\hline & $45 \mathrm{~min}$ & $6,69+$ & $247+$ & $42+$ & $-34,1+$ & $29,5+$ \\
\hline \multirow{4}{*}{$\mathrm{MHN}_{\text {Halothane+SCh }}(\mathrm{n}=10)$} & $0 \mathrm{~min}$ & $7,41[7,41-7,48]$ & 262 [242-291] & 36 [35-38] & $1,0[-1,9-3,3]$ & $1,1[0,9-1,4]$ \\
\hline & $15 \mathrm{~min}$ & $7,44[7,37-7,46]$ & 243 [231-274] & $37[36-41]$ & $0,3[-21-2,8]$ & $1,1[0,9-1,4]$ \\
\hline & $30 \mathrm{~min}$ & $7,38[7,35-7,44]$ & 238 [216-274] & 37 [36-38] & $-0,4[-3,6-1,5]$ & $1,3[1,0-1,4]$ \\
\hline & $45 \mathrm{~min}$ & $7,37[7,34-7,43]$ & $239[205-253]^{*}$ & 39 [37-40] & $-2,3[-4,7--0,5]$ & $1,2[1,1-1,3]$ \\
\hline
\end{tabular}

$\mathrm{t}=0$ minutes: Baseline values; $\mathrm{t}=15$ minutes: Application of $4 \mathrm{mg} / \mathrm{kg}$ succinylcholine or $0.5 \mathrm{Vol} \%$ halothane or both; $\mathrm{t}=30 \mathrm{minutes}$ : Application of $4 \mathrm{mg} / \mathrm{kg}$ succinylcholine or $1 \mathrm{Vol} \%$ halothane or both.

$\mathrm{SCh}=$ succinylcholine; $\mathrm{PaO}_{2}=$ arterial oxygen partial pressure; $\mathrm{PaCO}_{2}=$ arterial carbon dioxide partial pressure; $\mathrm{BE}=$ base access

Data as median and interquartile range.

*significant changes from baseline values; " significant differences between MHS and MHN; $\mathrm{p}<0.05 .+$ : data from only one MHS animal.

Table 3 Femoral venous carbon dioxide partial pressure $\left(\mathrm{PCO}_{2}\right)$ of malignant hyperthermia susceptible (MHS) and non-susceptible (MHN) pigs following succinylcholine or halothane or succinylcholine and halothane application

\begin{tabular}{|c|c|c|c|c|}
\hline Diagnose & Femoral venous $\mathrm{PCO}_{2}[\mathrm{mmHg}] \mathrm{t}=0 \mathrm{~min}$ & $\mathrm{t}=15 \mathrm{~min}$ & $\mathrm{t}=30 \mathrm{~min}$ & $\mathrm{t}=45 \mathrm{~min}$ \\
\hline $\mathrm{MHS}_{\mathrm{SCh}}(\mathrm{n}=9)$ & $51[45-54]$ & 52 49-56] & $78[67-93]^{* \#}$ & $79[72-105]^{* \#}$ \\
\hline $\mathrm{MHN}_{\mathrm{SCh}}(\mathrm{n}=10)$ & $50[43-55]$ & $49[44-54]$ & $51[45-56]$ & $49[43-56]$ \\
\hline $\mathrm{MHS}_{\text {Halothane }}(n=6)$ & $59[46-67]$ & $55[45-60]$ & $71[58-84]^{*}$ & $138[98-152]^{* \#}$ \\
\hline MHN Halothane $(n=10)$ & 50 [44-58] & $52[44-57]$ & $54[44-58]$ & 54 [44-60] \\
\hline $\mathrm{MHS}_{\text {Halothane+SCh }}(\mathrm{n}=12)$ & $51[47-56]$ & $57[53-64]$ & $151[110-192]^{* \#}$ & $199+$ \\
\hline $\mathrm{MHN}_{\text {Halothane+SCh }}(\mathrm{n}=10)$ & $51[44-53]$ & $49[44-52]$ & $50[47-57]$ & $51[47-61]$ \\
\hline
\end{tabular}

$\mathrm{t}=0$ minutes: Baseline values; $\mathrm{t}=15$ minutes: Application of $4 \mathrm{mg} / \mathrm{kg}$ succinylcholine or $0.5 \mathrm{vol} \%$ halothane or both; $\mathrm{t}=30 \mathrm{minutes}$ : Application of $4 \mathrm{mg} / \mathrm{kg}$ succinylcholine or 1 vol\% halothane or both.

$\mathrm{SCh}=$ succinylcholine.

Data as median and interquartile range.

*significant changes from baseline values; ${ }^{\#}$ significant differences between MHS and MHN; $\mathrm{p}<0.05$. +: data from only one MHS animal. 
Table 4 Muscular carbon dioxide partial pressure $\left(\mathrm{PCO}_{2}\right)$ of malignant hyperthermia susceptible (MHS) and non-susceptible (MHN) pigs following succinylcholine or halothane or succinylcholine and halothane application

\begin{tabular}{|c|c|c|c|c|}
\hline Diagnose & Muscular $\mathrm{PCO}_{2}[\mathrm{mmHg}] \mathrm{t}=0 \mathrm{~min}$ & $t=15 \min$ & $t=30 \min$ & $\mathrm{t}=45 \mathrm{~min}$ \\
\hline $\mathrm{MHS}_{\mathrm{SCh}}(\mathrm{n}=9)$ & $60[45-64]$ & 59 [45-62] & $73[65-87]^{* \#}$ & $78[69-92]^{* \#}$ \\
\hline $\mathrm{MHN}_{\mathrm{SCh}}(\mathrm{n}=10)$ & $54[41-59]$ & $55[46-60]$ & $56[47-59]$ & $58[50-60]$ \\
\hline $\mathrm{MHS}_{\text {Halothane }}(n=6)$ & $54[51-58]$ & $54[50-57]$ & $59[57-71]$ & $106[101-120]^{* *}$ \\
\hline $\mathrm{MHN}_{\text {Halothane }}(\mathrm{n}=10)$ & $59[48-63]$ & $58[49-62]$ & $54[48-63]$ & $56[48-60]$ \\
\hline $\mathrm{MHS}_{\text {Halothane+SCh }}(\mathrm{n}=12)$ & $56[48-60]$ & $56[47-66]$ & $114[56-167]$ & $140+$ \\
\hline $\mathrm{MHN}_{\text {Halothane+SCh }}(\mathrm{n}=10)$ & $56[54-65]$ & $56[47-66]$ & $56[55-65]$ & $58[56-68]$ \\
\hline
\end{tabular}

$\mathrm{t}=0$ minutes: Baseline values; $\mathrm{t}=15$ minutes: Application of $4 \mathrm{mg} / \mathrm{kg}$ succinylcholine or 0.5 vol\% halothane or both; $\mathrm{t}=30 \mathrm{minutes}$ : Application of $4 \mathrm{mg} / \mathrm{kg}$ succinylcholine or 1 vol\% halothane or both.

$\mathrm{SCh}=$ succinylcholine.

Data as median and interquartile range

*significant changes from baseline values; " significant differences between MHS and MHN; $\mathrm{p}<0.05 .+$ : data from only one MHS animal.

rapid and excessive rise of venous $\mathrm{PCO}_{2}$ levels (Table 3 ). The changes of muscular $\mathrm{PCO}_{2}$ values were similar to the femoral venous results. $\mathrm{SCh}$ induced a significant, but compared to halothane a minor increase of muscular $\mathrm{PCO}_{2}$. Simultaneous exposure of MHS pigs to SCh and halothane aggravated the changes of muscular metabolism (Table 4).

Noteworthy, in MHS animals application of halothane and/or SCh resulted in a more distinctive and rapid increase of $\mathrm{PCO}_{2}$ in the triceps muscle and in the femoral venous blood compared to $\mathrm{PaCO}_{2}$ and end-tidal $\mathrm{PCO}_{2}$ values. (Table 2, Table 3 and Table 4).

\section{Discussion}

The disturbance of intracellular calcium homeostasis due to an uncontrolled sarcoplasmic calcium release via mutated calcium releasing channels is widely accepted as the underlying pathophysiological mechanism of $\mathrm{MH}$. The excessive increase of skeletal muscular intracellular calcium levels in MHS individuals leads to muscle rigidity, enhanced mitochondrial energy turnover with excessive oxygen consumption, carbon dioxide increase, heat production and metabolic acidosis [1,6].

Undoubtedly, all volatile anaesthetics have the ability to provoke an $\mathrm{MH}$ episode [2]. For instance, it is well known that halothane induces an excessive sarcoplasmic calcium release in predisposed individuals via interaction with altered ryanodine receptors subtype 1, leading to the clinical syndrome of $\mathrm{MH}[7,8]$. The hemodynamic and above all the metabolic changes observed in this investigation with decrease of $\mathrm{pH}$ and $\mathrm{BE}$ combined with significant increases of end-tidal $\mathrm{PCO}_{2}, \mathrm{PaCO}_{2}$ and lactate following halothane exposition in MHS swine documented once again the $\mathrm{MH}$ inducing potency of volatiles.

In contrast, the underlying mode of action or the impact of SCh to elicit an $\mathrm{MH}$ remained unclear so far. Larach and colleagues rated 284 cases that were suspicious of $\mathrm{MH}$ and had been reported to the North American MH Registry using a clinical grading scale to evaluate the likelihood of truly being $\mathrm{MH}$. Only two cases $(0.7 \%)$ were regarded as "very likely" or "almost certain" being $\mathrm{MH}$, after SCh had been applied to the patients but not a volatile anaesthetic [9]. Recently, a European multicentre study analysed the cases of 200 patients with history of a clinical $\mathrm{MH}$ episode and confirmed $\mathrm{MH}$ disposition by in vitro contracture test. In this study only two patients (1\%; $1 \mathrm{MHS}$ and $1 \mathrm{MH}$ equivocal) with $\mathrm{SCh}$ induced $\mathrm{MH}$ crisis in absence of any inhalation anaesthetic were identified [10].

In animals, intramuscular injection of halothane resulted in a local hypermetabolic response with locally limited rise of lactate and $\mathrm{PCO}_{2}$, enabling a differentiation between $\mathrm{MH}$ susceptible and normal pigs [11], while local SCh did not initiate a metabolic reaction [12]. Furthermore, variable responses to intravenous SCh application were reported in susceptible swine. While in previous studies an $\mathrm{MH}$ episode could not be elicited with $\mathrm{SCh}$ alone $[13,14]$, Iaizzo and colleagues demonstrated that SCh induced porcine $\mathrm{MH}[15,16]$. However, the fact that acidosis and hypercapnia occurred shortly after SChinduced hypotension and tachycardia, which were treated with intravenous saline infusion does not exclude reperfusion of temporary hypoperfused tissue to be causal for the metabolic alterations [15]. In contrast to this previous study, in the presented investigation the decrease of arterial blood pressure induced by SCh was not treated. Hence, the observed metabolic reactions, including a decrease of $\mathrm{pH}$ and $\mathrm{BE}$ and an increase of end-tidal $\mathrm{PCO}_{2}, \mathrm{PaCO}_{2}$ and lactate as well as muscular and femoral $\mathrm{PCO}_{2}$ in susceptible pigs, are likely to be signs of a developing $\mathrm{MH}$. Even if the alterations after SCh were less distinctive compared to the halothane-induced effects, our results documented a severe metabolic stimulation in the susceptible animals.

Possible explanations for SCh-induced $\mathrm{MH}$ may be based on the pharmacological characteristics of this agent. After intravenous injection, $\mathrm{SCh}$ activates the nicotinergic acetylcholine receptor, which acts as an unspecific cation channel provoking a local depolarization of the cell 
membrane. The transient depolarization of voltage-gated receptors and an influx of extracellular calcium via the nicotinergic acetylcholine receptors followed by an increase of intracellular calcium levels may trigger $\mathrm{MH}$ in predisposed individuals [17]. In this context, muscular fasciculation and rigidity caused by $\mathrm{SCh}$ were considered to be causal for $\mathrm{MH}$, since pre-treatment with nondepolarizing muscle relaxants diminished or completely prevented the appearance of an $\mathrm{MH}$ episode $[15,16,18]$. Thereby, the rise of intracellular calcium during the depolarisation period itself might be sufficient to initiate sarcoplasmic calcium release and after exceeding individual thresholds, $\mathrm{MH}$ occurs in affected individuals. Similar to previous studies prolonged fasciculation was seen in the investigated MHS pigs. However, the importance and the exact mode of action of SCh in setting off an $\mathrm{MH}$ episode are still indistinct and require further research.

In the current study, simultaneous application of halothane and succinylcholine potentiated the induced hemodynamic and metabolic effects compared to the changes following administration of halothane or SCh alone in MHS swine. Interestingly, a significant rise of body temperature only occurred after administration of a combination of both pharmacological agents, reflecting the severe metabolic breakdown. Our findings suggest an additive effect of $\mathrm{SCh}$ as postulated by previous investigations in which the onset of an $\mathrm{MH}$ episode was significantly enhanced and the increase of serum creatine kinase was more pronounced after a combination of SCh and volatile anaesthetics $[10,19,20]$.

Hypermetabolism during a fulminant $\mathrm{MH}$ episode is typically associated with an excessive increase of endtidal and arterial carbon dioxide concentrations $[1,6]$. The more distinctive rise of femoral venous and muscular $\mathrm{PCO}_{2}$ levels compared to $\mathrm{PaCO}_{2}$ and end-tidal $\mathrm{PCO}_{2}$ in MHS swine might be caused by a significant muscular venous outflow of carbon dioxide. Hence, blood gas analysis of venous blood might be as helpful as an arterial blood gas in clinical practice for real time detection of a developing $\mathrm{MH}$ episode.

\section{Conclusions}

In conclusion, the findings of our investigation clearly demonstrated, that both SCh and halothane alone had the ability to induce an $\mathrm{MH}$ in susceptible swine. Furthermore, the observed hemodynamic and metabolic effects were excessively potentiated by combination of both pharmacological agents. Based on these results, SCh acts independent as well as supportive to provoke an $\mathrm{MH}$ episode in predisposed individuals. Hence, even if convincing reports of fulminant $\mathrm{MH}$ in humans induced by $\mathrm{SCh}$ alone are lacking, the obtained findings of our study proved the $\mathrm{MH}$ eliciting potency of SCh. However, the underlying mode of action of SCh to cause an $\mathrm{MH}$ episode still remains unclear and needs to be evaluated in further investigations.

\section{Abbreviations}

BE: Base excess; IVCT: In vitro contracture test; MAP: Mean arterial blood pressure; MH: Malignant hyperthermia; MHN: Malignant hyperthermia non-susceptible; MHS: Malignant hyperthermia susceptible; $\mathrm{PaCO}_{2}$ : Arterial carbon dioxide pressure; $\mathrm{PaO}_{2}$ : Arterial oxygen partial pressure; $\mathrm{PCO}_{2}$ : End-tidal carbon dioxide partial pressure; $\mathrm{SaO}_{2}$ : Peripheral oxygen saturation; SCh: Succinylcholine.

\section{Competing interests}

All authors declare that they have no competing interests.

\section{Authors' contributions}

FS conceived the study, accompanied the data acquisition, collected the data and drafted the manuscript. SJ analyzed the data and helped writing the manuscript. SM analyzed the data. TM collected the data. NR participated in the design of the study. MA participated in the design of the study, collected and analyzed the data. All authors read and approved the final manuscript.

\section{Acknowledgements}

Chief technician Judith Skirde (Malignant Hyperthermia laboratory, University of Wuerzburg, Germany) contributed essential advice and technical assistance throughout the study.

The study was performed at the Department of Anesthesia and Critical Care at the University of Wuerzburg, Germany.

The results of this investigation were presented in part at the Annual Meeting of the American Society of Anesthesiology in Washington D.C., U.S.A., October 2012 and at the Annual Meeting of the European Malignant Hyperthermia Group in Basel, Switzerland, May 2013.

Publication of this investigation was funded by the German Research Foundation (DFG) and the University of Wuerzburg in the funding programme Open Access Publishing.

\section{Author details}

${ }^{1}$ Department of Anaesthesia and Critical Care, University of Wuerzburg, Oberduerrbacher Straße 6, D-97080 Wuerzburg, Germany. ${ }^{2}$ Department of Anaesthesiology, University of Regensburg, Regensburg, Germany.

${ }^{3}$ Department of Anaesthesia, Hospital Landshut-Achdorf, Landshut, Germany.

\section{Received: 25 October 2013 Accepted: 5 March 2014}

Published: 7 March 2014

\section{References}

1. Schuster F, Müller-Reible CR: [Malignant hyperthermia-diagnostics, treatment and anaesthetic management]. Anasthesiol Intensivmed Notfallmed Schmerzther 2009, 44:758-763.

2. Hopkins PM: Malignant hyperthermia: pharmacology of triggering. Br J Anaesth 2011, 107:48-56.

3. Metterlein T, Schuster F, Kranke P, Roewer N, Anetseder M: In-vitro contracture testing for susceptibility to malignant hyperthermia: can halothane be replaced? Eur J Anaesthesiol 2011, 28:251-255.

4. Galloway GJ, Denborough MA: Suxamethonium chloride and malignant hyperpyrexia. Br J Anaesth 1986, 58:447-450.

5. Schuster F, Johannsen S, Schneiderbanger D, Roewer N: Evaluation of suspected malignant hyperthermia events during anesthesia. BMC Anesthesiol 2013, 13:24.

6. Bandschapp O, Girard T: Malignant hyperthermia. Swiss Med Wkly 2012, 31:142.

7. Kunst G, Graf BM, Schreiner R, Martin E, Fink RH: Differential effects of sevoflurane, isoflurane, and halothane on $\mathrm{Ca} 2+$ release from the sarcoplasmic reticulum of skeletal muscle. Anesthesiology 1999, 91:179-186.

8. Diaz-Sylvester PL, Porta M, Copello JA: Halothane modulation of skeletal muscle ryanodine receptors: dependence on $\mathrm{Ca} 2+, \mathrm{Mg} 2+$, and ATP. Am J Physiol Cell Physiol 2008, 294:1103-1112.

9. Larach MG, Gronert GA, Allen GC, Brandom BW, Lehman EB: Clinical presentation, treatment, and complications of malignant hyperthermia in North America from 1987 to 2006. Anesth Analg 2010, 110:498-507.

10. Klingler W, Heiderich S, Girard T, Gravino E, Heffron J, Johannsen S, Jurkat-Rott K, Rüffert H, Schuster F, Snoeck M, Sorrentino V, Tegazzin V, Lehmann-Horn F: 
Functional and genetic characterization of clinical malignant hyperthermia crises: a multicenter study. Orphanet J Rare Dis 2014, 9:8.

11. Schuster F, Schöll H, Hager M, Müller R, Roewer N, Anetseder M: The dose-response relationship and regional distribution of lactate after intramuscular injection of halothane and caffeine in malignant hyperthermia-susceptible pigs. Anesth Analg 2006, 102:468-472.

12. Metterlein T, Schuster F, Palmer E, Roewer N, Anetseder M: Succinylcholine in malignant hyperthermia: evaluation of a novel in vivo model. Muscle Nerve 2011, 44:213-216.

13. Hall LW, Trim CM, Woolf N: Further studies of porcine malignant hyperthermia. Br Med J 1972, 15:145-148.

14. Nelson TE, Jones EW, Bedell DM: Porcine malignant hyperthermia: a study on the triggering effects of succinylcholine. Anesth Analg 1973, 52:908-911.

15. laizzo PA, Wedel DJ: Response to succinylcholine in porcine malignant hyperthermia. Anesth Analg 1994, 79:143-151.

16. Sigg DC, laizzo PA: Malignant hyperthermia phenotype: hypotension induced by succinylcholine in susceptible swine. Anesthesiology 2000, 92:1777-1788.

17. Noronha-Blob L, Gover R, Baumgold J: Calcium influx mediated by nicotinic receptors and voltage sensitive calcium channels in SK-N-SH human neuroblastoma cells. Biochem Biophys Res Commun 1989, 162:1230-1235.

18. Harrison GG: Anaesthetic-induced malignant hyperpyrexia: a suggested method of treatment. Br Med J 1971, 3:454-456.

19. Pollock AN, Langton EE, Couchman K, Stowell KW, Waddington M: Suspected malignant hyperthermia reactions in New Zealand. Anaesth Intensive Care 2002, 30:453-461.

20. Antognini JF: Creatine kinase alterations after acute malignant hyperthermia episodes and common surgical procedures. Anesth Analg 1995, 81:1038-1042.

doi:10.1186/1471-2253-14-14

Cite this article as: Schuster et al:: The effect of succinylcholine on malignant hyperthermia events in susceptible swine. BMC Anesthesiology 2014 14:14

\section{Submit your next manuscript to BioMed Central and take full advantage of:}

- Convenient online submission

- Thorough peer review

- No space constraints or color figure charges

- Immediate publication on acceptance

- Inclusion in PubMed, CAS, Scopus and Google Scholar

- Research which is freely available for redistribution 